ELORE (ISSN 1456-3010), vol. 20 - 2/2013.

Julkaisija: Suomen Kansantietouden Tutkijain Seura ry.

[http://www.elore.fi/arkisto/2_13/savolainen.pdf]

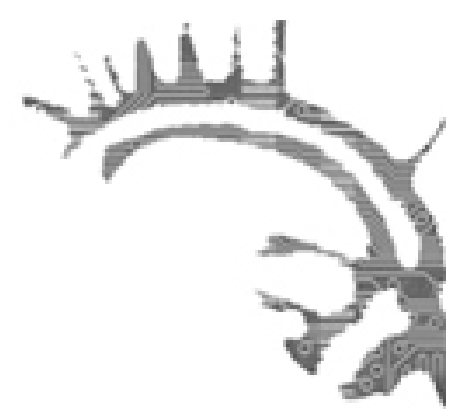

\title{
KIRJA-ARVIO
}

\section{LEHMÄSTÄ ON MONEKSI}

\author{
Ulla Savolainen
}

KAARLENKASKI, TAIJA 2012: Kertomuksia lehmästä. Tutkimus ihmisen ja kotieläimen kulttuurisen suhteen rakentumisesta. Kultaneito IX. Joensuu: Suomen Kansantietouden Tutkijain Seura. 385 s.

"[L]ehmä voi edustaa monia asioita: tyhmyyttä, viisautta, kömpelyyttä ja kauneutta, alistuvaisuutta ja päättänäisyyttä, lempeyttä ja äkäisyyttä, turvaa ja pelkoa." (S. 323.) Näin Taija Kaarlenkaski kuvaa väitöskirjassaan Kertomuksia lehmästä suhtautumistapojen ja merkitysten moninaisuutta, joita suhde lehmään voi herättää. Lehmästä myös kerrotaan - kirjoitetaan - moninaisin tavoin, erilaisia retorisia vaikutelmia luoden, kuten Kaarlenkaski runsaassa ja moniulotteisessa tutkimuksessaan osoittaa.

\section{LEHMÄKERRONNAN TARKASTELUN LÄHTÖKOHDAT}

Kaarlenkaski tutkii ihmisen ja lehmän kulttuurisen suhteen rakentumista Suomalaisen Kirjallisuuden Seuran (SKS) ja Maaseudun sivistysliiton (MSL) vuonna 2004järjestämän Ei auta sanoi nauta -kirjoituskilpailun aineistossa. Tutkimuksen kysymykset liittyvät siihen, kuinka suomalaista lehmäsuhdetta representoidaan ja rakennetaan kirjoittamalla. 
Ulla Savolainen: Lehmästä on moneksi

Tutkimuskohde versoo kahtaalle, sillä sen polttopisteessä ovat toisaalta kirjoituskilpailutekstit kerrontana ja toisaalta lehmän niissä saamat merkitykset.

Kaarlenkasken tutkimukselleen asettamat tavoitteet ovat monipuoliset ja kunnianhimoiset. Epäilemättä niistä olisi ollut ainesta kahteen tutkimukseen. Ne edellyttävät myös monipuolista metodologista lähestymistapaa, jonka esittely tapahtuu pääosin tutkimuksen ensimmäisessä johdanto-osassa. Yleisluontoisena epistemologisena viitekehyksenä väitöskirjassa ovat ensinnä konstruktionistinen tiedonkäsitys, jonka mukaan tieto on sosiaalisesti ja kielellisesti rakentunutta, sellaisenaan sidoksissa konteksteihin ja näkökulmiin, sekä toisaalta posthumanistinen ajattelu, joka pyrkii kyseenalaistamaan ja kriittisesti tarkastelemaan luonnon ja kulttuurin välistä rajaa ja sen tuottamista. Tutkimus paikantuu monitieteiseen kerronnan tutkimukseen, erityisesti kulttuurintutkimuksen ja perinnetieteiden piirissä tehtyyn kerronnan ja keruuaineistojen tutkimukseen sekä ihmistieteelliseen eläintutkimukseen, joka tarkastelee ihmisten ja eläinten välisiä erilaisia vuorovaikutussuhteita. Väitöskirjan keskeiset käsitteet ovat kertomus, sukupuoli, ruumis ja tunne.

Kertomuksia lehmästä-tutkimuksen lähestymistavat on esitelty johdonmukaisesti ja perusteellisesti. Kaarlenkaski perustelee ja arvioi metodologisia valintojaan, jotka onnistuneesti ja kattavasti pohjustavat kysymyksiä, joihin Kaarlenkaski pyrkii tutkimuksessaan vastaamaan. Tästä huolimatta, tai siitä johtuen, johdantoluvussa on kuitenkin hienoista toistoa, joka häiritsee luvun rakenteen hahmottamista. Toistoa olisi voinut karsia esimerkiksi käsittelemällä erityisesti Ei auta sanoi nauta -aineistoon ja yleisesti kirjoituskilpailuaineistoihin liittyvää problematiikkaa samassa yhteydessä. Lukijana myös yllätyin, kun metodologisten lähtökohtien erittely jatkui lukutapojen erittelynä tutkimuksen seuraavassa tutkimusaineiston kerronnallisuuteen keskittyvässä osassa.

Kaarlenkaski paikantaa tutkimuksensa varsinaisen metodin, lukutavan, laajasti narratiivisen tutkimuksen piiriin, johon hän lukee myös narratologian. Tutkimuksen yleisluontoisempi metodologinen viitekehys paikantuu retoriseen kertomusteoriaan ja metodiset välineet nousevat narratologiasta juonnetuista kertomusten rakennetta jäsentävistä käsitteistä. Myös omaelämäkerrallisuus ja tekstien fiktionaalisuus ovat näkökulmia, joiden läpi Kaarlenkaski aineistoaan lukee. Varsinaiseksi menetelmäkseen Kaarlenkaski on valinnut kontekstualisoidun tai teoreettisesti informoidun lähiluvun. Koska tutkimuksen varsinaisia metodeja ei esitellä johdannossa vaan kerronnalliseen analyysiin keskittyvän toisen osan alussa, jää näiden metodien suhde kolmanteen, lehmäkerronnan temaattisiin sisältöihin keskittyvään osaan ja siellä tehtyihin tulkintoihin hieman epäselväksi.

\section{KERRONNAN MUOTOJEN JA MERKITYSTEN JÄLJILLÄ}

Tutkimuksen toisessa osassa Kaarlenkaski keskittyy analysoimaan lehmäkertomusten kerronnallista ulottuvuutta. Hän hahmottaa neljä aineiston pohjalta tyyliteltyä kertomustyyppiä, omaelämäkerralliset, etnografiset, lehmänäkökulmaiset sekä fiktionaaliset kertomukset, mutta kysyy myös kiinnostavasti, miten ne kuvaavat ihmisen ja lehmän 
suhdetta. Tuodakseen aineiston moninaisuutta ja tulkinnan syvyyttä esiin Kaarlenkaski lähilukee yhden kutakin tekstityyppiä edustavan kirjoituksen. Lähilukuun pohjautuvat analyysit kokonaisista kirjoitus- tai vastauskokonaisuuksista ovat monipuolisia, näkökulmia avartavia ja sellaisenaan hyvin rakennettuja ja lukijalle nautinnollisia lukukokemuksia tarjoavia pienoistutkielmia. Kaarlenkasken luokitus on perusteltu ja antaa tutkimuksen aineistosta heterogeenisyydessään kattavan kuvan. Se tarjoaa kiinnostavan vertailukohdan myös muiden teema- ja omaelämäkertakeruuaineistojen tyypillisten piirteiden hahmottamiselle.

Erityisen tärkeää ja tuoretta antia tutkimuksessa ovat lehmänäkökulmaisten ja fiktionaalisten kertomustyyppien analyysit, sillä tämänkaltaista kaunokirjallisuutta lähentyvää kerrontaa ei ole vielä kovin runsaasti tutkittu folkloristiikassa eikä pohdittu sen merkityksiä. Fiktionaalisuuden käsitteellä Kaarlenkaski viittaa kerronnan keinoon ja tekstin ominaisuuteen, joka synnyttää tietynlaisia retorisia vaikutelmia lukijassa, ei niinkään tekstin totuusarvoon tai sepitteellisyyteen. Kaarlenkaski esittää, että fiktionaalisessa kerronnassa kirjoittajien on mahdollista ilmaista asioita, arvoja ja tunteita, joita on vaikea ilmaista muiden (usein omaelämäkerrallisten) kerronnan muotojen tai genrejen puitteissa. Tämä on tärkeä huomio. Kaunokirjallista kerrontaa lähenevien kirjoitusten merkitysten analysointi ja ylipäätään niiden nostaminen tutkimuskohteiksi on merkittävää, mikäli perinnettä ja sen ilmenemismuotoja, ihmisten ilmaisun sekä kulttuuristen merkitysten välittämisen ja tuottamisen keinoja, halutaan ymmärtää nykykulttuurin kontekstissa. Pyrkimällä ymmärtämään sitä, mitä kirjoittajat tekevät ja haluavat sanoa, Kaarlenkaski nähdäkseni toteuttaa myös keskeistä tutkimuseettistä periaatettaan, tutkittavien oikeudenmukaista, rehellistä ja kunnioitettavaa kohtelemista. Kaarlenkasken tutkimus jatkaa tärkeillä urilla myös kirjallisuustieteen menetelmien soveltamisen kehittelyssä folkloristiikan ja etnologian piirissä.

\section{KOHTAAMISIA LEHMÄN KANSSA}

Kaarlenkasken väitöskirjan temaattinen osa keskittyy tarkastelemaan erilaisia lehmän ja ihmisen kohtaamisen kuvauksia. Kaarlenkaski on kiinnostunut yhtäältä karjanhoitotyön kuvauksista ja kirjoittajien tulkinnoista lehmän osasta siinä, toisaalta lehmäsuhteista ja -suhtautumisista karjanhoitotyön ulkopuolella. Hän nostaa analyysissään esiin muun muassa lasten ja lehmän sekä kaupunkilaisen ja lehmän välisen suhteen sekä tuo esiin moninaisia suhtautumisia lehmään ja sen luonteeseen. Myös lehmään liitettyjä sukupuolittuneisuuden ilmaisuja, sukupuolittuneen lehmäsuhteen kerronnallista tuottamista sekä fiktionaalisten kirjoitusten lehmäkuvauksia tarkastellaan.

Erityisen sykähdyttävästi Kaarlenkaski tulkitsee lehmän lypsämisen ja poikimisen kuvauksia, joiden analyysissä ruumiillisuuden ja sukupuolen käsitteet ovat osuvia. Kaarlenkaski lukee kuvauksia intra-aktion, eräänlaisen saumattoman yhteisyyden kokemuksen ilmauksina. Tämänkaltaisissa kokemuksissa liikutaan kahden toimijan vuorovaikutuksen yläpuolella, eräänlaisessa saumattomassa yhteisyyden kokemuksessa, jossa on mahdollista ikään kuin ylittää subjektien ja lajien välisiä rajoja. Lukiessani Kaarlenkasken analyysia 
Ulla Savolainen: Lehmästä on moneksi

pohdin siinä esitettyjä näkökulmia myös suhteessa juuri lukemaani Anu Silfverbergin esseekokoelmaan Äitikortti, jonka eräässä kirjoituksessa Silfverberg käsittelee tuotantoeläimiä sekä liha- ja maitoteollisuutta äitiyden ja imetyksen kokemuksen mukanaan tuoman henkilökohtaisen ja ruumiillisen tunteiden läpi suodattuvan näkökulman lävitse. Samankaltaiset kokemukset Kaarlenkasken aineiston kirjoittajien ja Silfverbergin, tuotantoeläimien kanssa etäisessä suhteessa elävän kaupunkilaisen, välillä osoittavat sen, että ihmisen ero ja etäisyys eläimeen eivät ole kovinkaan suuria, tai ainakin ruumiin kokemuksen ja empatian avulla niitä on mahdollista kuroa lyhyemmiksi.

\section{MONINAISEN AINEISTON TUTKIMISEN VAIKEUS JA RIKKAUS}

Taija Kaarlenkasken väitöskirjatutkimuksen fokusta voisi luonnehtia kaksinaiseksi, missä piilee nähdäkseni tutkimuksen vahvuus ja heikkous. Kaarlenkaski keskittyy analysoimaan kerrontaa toimintana, tekemisinä ja rakenteina sekä kerronnassa esiin tulevina teemoina ja sisältöinä. Tämä kaksijakoisuus käy ilmi myös väitöskirjan rakenteessa sen analyysilukujen jakautuessa selkeästi kahteen osaan. Kaarlenkasken tulkinnat molemmissa osissa ovat perusteltuja, oivaltavia ja osoittavat aineiston syvää tuntemusta, mutta erityisesti kirjoitusten kerronnallisesta puolesta kiinnostuneena lukijana olisin toivonut, että Kaarlenkaski olisi tuonut myös lopun temaattisissa luvuissa enemmän esiin kerronnan tasolta nousevaa tulkintaa yhdistettynä teemojen analyysiin. Tämä on yleinen ja sangen ymmärrettävä, keruukirjoitusten valtavasta muodollisesta ja temaattisesta heterogeenisyydestä kumpuava ongelma, mutta kerronnan tutkimukseen laajasti perehtyneen tekijän olisi toivonut analyysissään vielä tiiviimmin limittämään temaattisen ja kerronnallisen analyysin tasot ja näin ollen saattamaan ne syvempään vuoropuheluun.

Kaarlenkaski onnistuu tuomaan tutkimuksessaan sekä sen monipuolisessa kysymyksenasettelussa esiin tutkimusaineiston olennaisen piirteen: sen kerronnallisen ja temaattisen moninaisuuden. Lehmästä kerrotaan monella eri tavalla ja kertomusten tavoitteet ovat erilaisia. Kaarlenkaski esittää loppuluvussa myös tulkintansa tutkimusaineistonsa peilaamasta niin kutsutusta "suuresta kertomuksesta" ja siihen liittyvistä vastakertomuksista. Tämä analyysi yhdistettynä aineiston käsittelyn näkökulmien moninaisuuteen ja sen tarjoamien näkökulmien heterogeenisyyden korostamiseen on vakuuttava ja toimii tulkinnan kattotasona. Kaarlenkasken mukaan suuri kertomus esittää agraarikulttuuriin usein idealisoivasti ja nostalgisesti. Sen puitteissa lehmä ja karjanhoito esitetään osana kansallista identiteettiä ja kansakunnan rakentamista. Suuren kertomuksen rinnalla elävät myös kriittiset vastakertomukset, joissa naudan elämän ei niin sulostuttavat puolet, kuten sen asema ihmisen hyödyn välineenä, tuotantoeläimenä tai pelottavana ja vaarallisena olentona, tulevat esiin. 
Ulla Savolainen: Lehmästä on moneksi

\section{KiRJALlisuUS}

SILFVERBERG, ANU 2012: Äitikortti. Kirjoituksialisä̈ntymisestä. Helsinki: WSOY.

Filosofian maisteri Ulla Savolainen on folkloristiikan jatko-opiskelija Helsingin yliopistossa ja valmistelee väitöskirjatutkimusta Karjalaisten evakkolasten muistelukirjoituksista. 